\title{
KTMBEERTEY'S MODEL COMPOUNDS
}

by

Rob Turrell

In 1903 a private commission of Rand compound managers visited the Kimberley diamond mine compounds "with a view to the application of their system to the Witwatersrand mines if deemed advantageous". (1) The commission went to the diamond mines because of Kimberley's reputation for model compounds. It was commonly believed by mine owners and others that good accommodation, food and health care for African miners were responsible, in part, for keeping up the full complement of the De Beers work force. Unlike on the Rand, there was no major shortage of labour in Kimberley after the war. "The De Beers Company have set an example of just and reasonable treatment of their Native employees", wrote Outlook, famous organ of Christian mission opinion, in 1906,

which might with advantage be followed at other South

African labour centres. What has been done at

Kimberley could be done elsewhere and it is

unfortunate that in other great labour centres the

employers do not take the same view of their

responsibilities. (2)

The Rand compound managers did, at least, learn from their visit to Kimberley. They recommended the construction of "Ideal compounds" on the Rand on the basis of what they saw at the diamond mines. Thus, the Kimberley compounds provided a model of social welfare for compounds on the Rand.

After the war the new British administration in the Transvaal was concermed over the high rate of African mortality on the gold mines. In 1903 it reached 71.25 deaths per thousand and had been as bad, if not worse, in the 1890s. (3) "I do not see", wrote Iyttelton, the Colonial Secretary, to Lord Milner, Governor of the Transvaal, "how a death rate of between 50 and 100 per thousand can be defended ...". (4) This mortality rate became an important issue in the debate over the introduction of Chinese workers to the Rand mines. Milner did all he could to improve compound conditions in view of the British and Chinese governments' negotiations over the conditions regulating the importation of Chinese into the Transvaal. (5) Rand mine doctors believed that the death rate could be reduced to 40 per thousand and, it seems, this was acceptable to Iyttelton. (6) The mine doctors and compound managers introduced improvements in the matters of sanitation, impervious floors, open stoves, diet, housing and hospitals. (7) As a result the mortality rate dropped to 42.62 per thousand in 1904 but thereafter failed to match the lower Kimberley death rate, which averaged 19.78 between 1903 and 1912. (8)

Rhodesian mine managers also looked to Kimberley for a model for their compounds. A Rhodesian representative joined the Rand compound commission when it visited Kimberley in 1903. (9) But Southerm Rhodesian compounds derived no immediate benefit from this experience. In fact, van Onselen has argued that the Rhodesian 
mines had "for many years an even more appalling health record than the Rand ...".(10) Standards of health cannot, of course, be simply assessed by the death rate. But it is an immediate indicator of physical welfare that can be measured. At its worst the African death rate on Southern Rhodesian mines wa 75.94 per thousand in 1906. But it did steadily improve over the next thirty years. The death rate was highest between 1906 and 1915 when an average of 43.40 per thousand Africans died on the mines each year. (11) And the causes of death were quite clear. "The greatest killers of all on Rhodesian mines", wrote van Onselen, "were diseases which could be directly attributable to the inadequate diet and poor standards of accommodation for workers." (12) Pneumonia, as at Kimberley and the Rand, accounted for the greatest proportion of deaths. And pneumonia was a "disease of employment" which was found comparatively rarely in the rural labour catchment areas of Southern and Central Africa. (13)

The culpability for mortality on the Katangan copper mines is less clear. "It is, of course, impossible to determine", wrote Perrings,

just how much mortality rates among particular age groups were increased by their presence on the mines since it is certain that even in rural areas moxtality was high. (14)

What is clear is that Africans died in greater numbers on Katangan mines at their most dangerous than at any other mining centre in southerm and central Africa. Between 1913 and 1922 the average mortality rate was 71.31 per thousand each year.(15) And these figures conceal sharp variations in death rates of different African peoples and in recruited as opposed to voluntary workers. However, in the 1920s work and compound conditions began to improve. As sections of the labour force were stabilized there was greater investment in medical care, housing and rations. After 1932 the rate of mortality due to disease remained consistently below 10 per thousand each year. (16) Katanga came to rival Kimberley in the humanity of its health record.

While general improvement in the conditions of mine labour occurred after an initial period of heavy mortality and labour shortage in southern and central Africa, Kimberley appears to have been an exception to the rule. Those few scholars who have written about Kimberley simply confirm the existence of model compounds almost from their introduction. (17) But what were Kimberley compounds like before they underwent fundamental reconstruction in 1903? Were they the models of social welfare that they were reputed to be? Or did they bear more brutally the birth maxks of another model, a model of labour control, the first of its kind in southern Africa and one that had initially little to do with the welfare of African miners?

\section{A Model of Social Welfare}

Mining companies began to introduce closed compounds in 1885 - fifteen years after. diamonds were first mined at Kimberley. For much of these first fifteen years Africans lived in open compounds. These compounds simply provided barrack-type accommodation for African miners. They provided lodgings for 20,000 Africans in their hey-day in the early 1880s. Open compounds were enclosed by corrugated-iron fences with guarded gates to regulate the movement of African workers. But Africans were free to go into the locations or townships to spend their leisure time on the food, drink and pleasure of their choice. The introduction of closed compounds ended this freedom. (18) Closed compounds were self-contained institutions. Once an African entered a closed compound he lost all access to the surrounding town for the duration of his contract. Food was sold in the compound stores and, in time, alcohol was prohibited. Africans moved between the mines and compounds through enclosed subways. And the large compounds were covered with a fine wire mesh to prevent parcels of stolen diamonds being thrown over the fences. This completed the total isolation of African workers in a world of their own. 
By 1889 all African mine workers $(10,000)$ were compounded. (19) Even before this process was completed, Gardner Williams, General Manager of De Beers Consolidated Mines Limited, which employed the majority of workers, was convinced that they were immense improvements in social welfare. "Our natives are better housed and better fed than uncompounded natives", he told his shareholders,

and are better paid than miners in any of the European countries. Those unfit for work, either through sickness or on account of injuries received in the mine are taken free of cost in the Company's hospital which adjoins the compound. There are fewer accidents under the present system than there were in the open workings. A very large majority of the accidents in the mine is due either to the carelessness or the stupidity of the natives themselves. A large percentage of the deaths in the compound had been caused by receiving natives who come in companies from countries north of the Transvaal, many of whom are so starved and emaciated as to be beyond help. (20)

There was much that was questionable in this statement. Most questionable was Williams' understanding of why Africans under his control and care died.

There is little doubt that there were more accidents in underground mining than in open working, which had been the system in use from 1870 to 1885 and in some mines after that date. It is also clear that diamond mining had a worse accident rate than gold mining to the north in their first thirty years of development. Some statistics prove the point. In late nineteenth century Britain over three persons killed per thousand in mining was considered unacceptable. (2I) On the Witwatersrand the death rate averaged a little over four per thousand between 1896 and 1905. In Southerm Rhodesia the mine death rate never went over five per thousand between 1907 and 1933. For the latter half of this period it averaged around two and a half deaths per thousand. Worst of all, the Kimberley accident death rate was nine and a half per thousand between 1881 and 1889, declining to 6.2 per thousand over the following decade. (22)

In part this high death rate was the product of the novel and treacherous nature of underground mining in diamondiferous ground (called blue). Vast caverns were excavated in the blue, transforming the Kimberley and De Beers mines into gigantic honeycombs. The blue left as pillars was inherently unsafe, as it disintegrated on exposure to the atmosphere and to water. There were also greasy slides between large blocks of blue, which slipped without warning. Consequently, the roofs of underground workings were constant sources of danger. Furthermore, fire-damp was a threat while candles were the major means of underground lighting. And, finally, mud rushes became the most feared underground hazard, bursting into tunnels and filling them up with terrifying speed. However, despite these manifest dangers to life, the Mining Inspector concluded in 1886 that "the majority of employers of labour in these mines look upon regulations for safety as mere harassing restrictions". (23)

The novel nature of mining and the treacherous quali ies of the blue were exacerbated by competition to increase production in the late 1880s. The De Beers DMC (24) pushed its workers to the limit to catch up with the greater productive capacity of the Kimberley Central IMC so as to improve its stake in the struggle for total control of the four mines. In doing so the De Beers management flouted safety regulations, with catastrophic results. (25) In July 1888, soon after the formation of De Beers Consolidated, a fire broke out underground in De Beers mine. Out of a work-force of 67 Europeans and 625 Africans, 24 Europeans and 178 Africans died. (26) Such a disaster played havoc with accident statistics and mine managers preferred to exclude it and explain it as exceptional. (27) 
Accidents accounted, however, for only a proportion of the mortality rate at the diamond mines. Disease took the lion's share of lives. The contribution of closed compounds to the incidence of disease can best be seen in a comparison with open compounds. But this has its difficulties as large open compounds were in their hey-day during the depression and small-pox epidemic (1882-1885). Both depression and small-pox exacerbated mortality. And as small-pox drove away labourers in fear of their lives and drove up the price of mining materials, the mine owners, in particular, tried to conceal the nature of the epidemic and its deadly legacy. The mortality statistics for this period are, therefore, distinctly unreliable. (28)

However, it is possible to compare the mortality rate in the two boom periods of the late 1870s and the late 1880s. But first some caveats should be made. The mortality rates apply to the whole population and not simply to those who worked in the mines. However, it should be remembered that the African population was overwhelmingly male, that African males were predominantly employed in the mining industry and that the death rate was highest among African male adults. In 1878, when African miners lived in open compounds, the African death rate was 80 per thousand. This was "a rate", wrote Dr Matthews,
which is sufficiently large to rank Kimberley among the most unhealthy towns in existence. This is about three times the proportionate rate of mortality in London and is considerably greater than the average number of deaths per 1,000 in large and crowded cities of the East. (29)

But a decade later matters were even worse. In 1888, when African miners lived largely in closed compounds, the African death rate was over 100 per thousand. (30) This was more than double the Rhodesian death rate in a comparable period of mining development. Even if we take into account the unreliability of total Kimberley population figures, we know that the trend in the earlier period was towards an increase in population while the converse was true of the second period. This tends to improve the earlier but worsens the later mortality rate. "The death rate is not as low as might have been reasonably expected", wrote the Registrar of Natives in 1888, "especially considering the increased compound accommodation". (31) Thus, Gardner Williams was far off the mark in his claim that closed compounds had increased the social welfare of African miners.

Medical practitioners in Kimberley advanced three explanations for the alarming increase in mortality in the late 1880s. Firstly, death registration improved after the small-pox epidemic had ended. It was openly admitted that many Africans had died without any official registration. Consequently, the horror of the extent of death in Kimberley became public for the first time. One Parliamentary Commission in 1887 discovered the fact that four convicts were continually employed in picking up African corpses from the streets, while another ten to thirty were employed full-time in digging graves. (32) The dead were generally newcomers, who had died of "starvation and exhaustion", having been driven out of compounds and locations by more frequent and rigorous pass raids. (33) Secondly, the accident death rate doubled after the development of underground mining. Admissions to the Kimberley Hospital rose and there was a sharp increase in compound fractures among the inquries. (34) Thirdly, doctors noticed that the majority of Africans died of pneumonia. And pneumonia deaths were a direct consequence of changes in mining production and inadequate compound accommodation.

This final point is brought into sharp relief through a comparison of the causes of death during the two eras of open compounds and open mining and closed compounds and underground mining. In the former era twice as many Africans died of fever, dysentery and diarrhoea as died of bronchitis, pneumonia, pthisis and pleurisy. (35) In the latter period the reverse was true. (36) Dysentery and diarrhoea were caused by defective sanitation, while lung diseases were attributable to overcrowded accommodation, poor diet and inadequate protection against major changes in temperature, all exacerbated by underground mining. While sanitation and 
public health improved over the 1880s and 1890s, De Beers did little to improve their compound accommodation in the ten or more years after the company monopolised production in 1889. Throughout the 1890 s pneumonia continued to be the biggest killer in the compounds. "The disease will continue to be our most serious cause of death in the ordinary course of events", wrote Dr Stoney in 1900, "so long as overcrowding in the compounds continues ...". (37)

Closed compounds were more overcrowded than open compounds. Overcrowding in open compounds had also been a problem but one compound differed from another. Some mining companies had achieved acceptable death rates, while others were cause for public disapproval. (38) There was little official regulation of compounds besides routine visits from the Sanitary Inspector. Such limited municipal authority was curtailed once De Beers Consolidated had monopolized production. Moreover, monopoly in production led to a centralization of compound accommodation. In 1889 there were seventeen compounds for 10,000 Africans. (39) In 1896 there were three compounds for the work force of 5,000 Africans. (40) Thus, as the number of compounds had dwindled they had expanded in size. The model De Beers West End compound covered five acres and contained the much vaunted swimming pool. But wide open spaces could not compensate for the congestion in the sleeping compartments. At the beginning of the $1890 \mathrm{~s}$ De Beers compounds infringed the public health minimal standards of 300 cubic feet per man. (4I) The situation worsened over the decade. Not only did systematic shift-work encourage the illusion that accommodation could be provided on shares. While one shift worked another slept. But also after 1896 the De Beer's work force began to expand once again without a commensurate expansion in compound accommodation. Thus, Dr Stoney was compelled to comment in 1900 that "until they [compounds] were extended and re-modelled with an increased air-space, proper lighting and impermeable floors, this terrible disease [pneumonia] amongst the natives will continue its ravages". (42)

Besides being overcrowded, compounds were also cold. Africans slept on the ground in blankets in quarters without doors and with an open space around the top of the walls. While this aided ventilation during summer and during the day, it did not exclude the intense cold at night and during winter. Kimberley was, and is, notorious for its savage inversions of temperature. In fact, compounds were so cold that one commission was told:

Natives for the night shift were in the habit of going down into the mine early in the afternoon because it was warmer there than in their compound, and that they would be about the mine smoking or sleeping, but always with lighted candles near them. (43)

Not only was De Beers parsimonious in the quantity of wood supplied, but also added insult to injury through the claim that wood was "free". Rather, wood was simply included in the costs of compound maintenance and recovered through the percentage placed on the goods bought in the compound stores. One government official questioned whether "in the face of the great amount of profits made out of these natives ... they receive anything for nothing". (44)

Another service De Beers claimed to provide "free of cost" was medical care. A review of the history of hospitals in Kimberley suggests otherwise. Sick Africans were most often sent to the Kimberley gaols. Prisons served a number of purposes besides their usual function of incarceration. They were "asylums for lunatics, hospitals for prisoners and chronic sick paupers and refuges for the destitute ...". (45) Their facilities were certainly free but medical care was minimal. Better treatment was available in the Kimberley Hospital but in the 1880s beds for Africans were limited. And this was so despite the fact that Africans paid a special hospital tax as part of the fee for the registration of a labour contract. This tex, which only Africans paid, provided the largest subsidy to the Kimberley Hospital throughout the 1880s and 1890s. The benefit of this funding largely went to white patients. None the less, it is clear that Africans were entitled to 
medical care, whether in mine or municipal hospitals, in return for the 12/- a year that they each paid. (46)

Were they compensated in the mine hospitals for the care they were entitled to at the Kimberley Hospital? It seems not. Before monopolization, companies varied in their standards of care, ranging from none at all in the Kimberley Central compound to a visiting doctor, dispensary and five or six nurses in the De Beers West End compound. (47) But whatever the level of health care, it was worse than the improving standards of medicine in the Kimberley Hospital. Compound managers did not take advantage of this. In fact, hospital authorities complained of Africans being sent to them "merely to die". (48) After this complaint at the turm of the decade, African workers were sent to Hospital before it was too late and the Hospital death rate declined. However, in the $1890 \mathrm{~s}$, as security in compounds was tightened against diamond theft, all African mine workers were treated in compound hospitals. And it is in the mine hospital deaths that a clear-cut mortality rate can be established. For there are no problems with an unreliable total population figure. Thus, between 1897 and 1902 the average annual African death rate in the diamond mines was 64.62 per thousand. (49) Although this was an improvement on the total (and therefore not strictly comparable) death rate in the 1880s, it was poor compared to the considerable improvements effected after 1903.

An inadequate diet contributed to this high death rate. Diamond workers were not rationed, as were black miners in Southern Rhodesia. They had to pay for their food individually or in food clubs and cook it themselves, or have it cooked for them by injured Africans unable to do mine work. There was a simple management reason for this. "If you were to ration the natives", said Francis "Matabele" Thompson, De Beers compound manager,

you would either find them all sick, or not wanting to work, because they would get their food all the same, whereas now they say we must work to get food. (50)

But often work was not available as more workers were compounded than were required for a full work force. In addition, management determined the price of food and the level of wages. Management control of work, wages and food prices ensured that a portion of the African work force was consistently undermourished.

In summary, then, the model of social welfare provided by Kimberley's compounds before 1903 was a poor one. After thirty years and more of diamond mining and fifteen under the closed compound system, African mortality was still

unacceptably high. Sanitation had improved and a section of the African work force had become acclimatized and accustomed to mine work. But pneumonia still continued to claim a high proportion - as high as 75 per cent - of those Africans who died on the mines. Mortality rates are blunt measures and conceal the effect of death and disease on different age groups and African peoples. But overall, the greatest improvement in Kimberley's health record took place after the reconstruction of the compound system in 1903. The most important facet of this was the building of new dormitories with double the cubic space per man of the old huts. Before this time managerial ideology massaged shareholders' sensibilities over welfare, while perfecting a model of labour control in the closed compounds.

\section{A Model of Labour Control}

In 1884, before the introduction of closed compounds, the De Beers DMC began negotiations with the Cape government over the conditions under which they would build their own convict station for the private use of convict labour in their work force. In January 1886 De Beers was granted a two-year contract for the free service of 300 convicts in return for which the company would maintain and discipline them in the convict station they had built. In 1888 the government 
renegotiated the contract and charged the company $-/ 3$ per day per man, a sum De Beers was glad to pay. (51) By this time De Beers was convinced that convicts were "superior to free labour in quantity, quality and reliability". (52) They showed their confidence in convicts by increasing the number employed from 220 in 1886 to 809 in 1894, limited only by the number available and the requirements of the Public Works Department, which had a first option on convicts. In fact, De Beers found convict labour so satisfactory that convicts were employed until 1932. (53)

Believing in the superiority of convict labour, closed compounds were modelled on the De Beers Convict Station. "In these convict barracks, or branch gaol", wrote the Mine Inspector, "the perfection of the compound system may be said to have been reached". (54) Compound managers tried to reproduce with free labour the advantages that $\mathrm{De}$ Beers found with convict labour. There were essentially five advantages: improvement in efficiency; greater discipline; cheaper labour; economies of scale in maintenance; and the prevention of diamond theft. In time, free labour in compounds and prison labour in the convict station became similar with "the only important difference being that between compulsory and voluntary service". (55) A look at the advantages of convict labour for De Beers provides an outline of the compound model of labour control.

The first major advantage of convict labour lay in its efficiency. "It is by far the best native labour we have", reported Gardner Williams, "owing to the fact that the convicts are obliged to remain for a considerable length of time, while the free natives only work two months at a time." (56) Convicts had more time to become accustomed to the hard regime of working about a mine. But De Beers did not always have long-service convicts. Before 1888 De Beers Convict Station seldom accommodated its full quota of prisoners. Competition with the Public Works Department forced De Beers to take convicts sentenced to less than two months' hard labour. Through this redefinition of long service the state shuffled off into private hands the costs of catering for convicts in overcrowded prisons. (57)

Kimberley prisons were overcrowded because of the enormous number of Africans who were convicted of pass offences. (58) They were sentenced to up to one month's imprisonment with hard labour. The Kimberley gaol had been "designed" for 400 convicts but in the late 1880s held twice that number. (59) For many "raw" Africans their introduction to the diamond city was a transit through the Kimberley gaol to the De Beers Convict Station. However, pass offenders did not become the trained mine labourers that De Beers required. In the 1890s, as the number of pass offenders and the prison population of Kimberley declined, De Beers looked to other convict stations in the Cape Colony for labour. Over the decade De Beers drew the majority of its long-term prisoners from the Transkei, Dordrecht and Middelburg. (60)

The second advantage of convict labour lay in the rigorous discipline and supervision that it was possible to impose on prisoners. Convicts were employed at the sorting tables and in breaking up the blue ground on the depositing floors (where the ground was laid out to weather after extraction from the mine). They were not employed underground, where even close supervision of free labourers was impossible. Convicts worked 13 hours a day in summer and $9 \frac{1}{2}$ hours in winter, a labour time which was two hours longer than the hard labour regulations of the Prison Department, but no longer than the hours worked by free labour. They were controlled by governmentappointed but company-paid Zulu guards, initially one to every five convicts, a ratio which widened to one to every ten convicts by 1891. (61)

The relaxation in supervision was a product of the expansion in convict employment in the 1890s and the use of some incentives to accompany the stick of prison discipline. For even though discipline was tight there were always ways in which convicts could sabotage their gaoler's property. Sabotage was made easier by the high value of diamonds and their often tiny size. Thus, a convict coming across a diamond while working on the floors or at the sorting tables had it "completely in his power to revenge himself on his employers either by sweeping the diamonds from 
the sorting tables or by burying them in the soil with his heel ...". (62) To discourage this, convicts were paid rewards of $-/ 3$ to $-/ 10$ per carat on found diamonds. Some convicts even left their periods of hard labour with more money than free labourers. A Parliamentary complaint led to a $ఓ 15$ limit per period of service being placed on this practice. (63) None the less, such a use of rewards was only possible in conjunction with total control over workers isolated in barrack-type accommodation.

A third advantage of convict labour was that it was cheaper than free labour. In 1885, before the construction of the station, convict labourers were not much cheaper than free labour. But between 1887 and 1894 the cost of discipline, maintenance and rent of convict labour declined from $£ 58$ to $₹ 39$ 10/per man per year. Free labour cost $\$ 65$ in 1887 but declined in proportion to convict labour, so that in 1894 it cost about $₹ 40$ per man per year. This decline in free labour wages from a maximum of 30/- a week to 12/- a week in 1894 was a direct consequences of amalgamation, the introduction of compounds and the use of convict labour as a constant reserve of workers. Thus, not only was convict labour initially cheaper than free labour, but it also served to depress the wages of the latter. (64)

Although convicts were cheaper to employ than free labour, their standards of maintenance were higher. In fact, the death rate at the De Beers Convict Station was 17.79 per thousand from 1891 to 1899 , increasing to 22.48 from 1900 to 1905. (65) Convicts were issued thick jumpers, moleskin trousers, felt hats, boots "when necessary", three blankets in winter and two in summer, and two sacks sewn together which formed a pillow and palliase to sleep on. As to diet, meat was the crucial element as hard labour could not be performed on a mealie meal (maize flour) diet: At the convict station men ate a pound of meat per day. In addition, convicts were entitled to a daily ration of a half-pound of bread, eight ounces of meal, one pound of vegetables, one ounce of salt and a quart of soup. (66)

The quality of rations in the De Beers Convict Station was certainly superior to the fare in the Kimberley gaols. There, convicts sentenced to over three months' hard labour were on a less beneficial meat diet, while under that term they were confined to a mealie meal diet. In 1884 gaol rations were reduced because of the high price of food and 350 long-term convicts went on strike. In consequence, rations were reduced below subsistence and scurvy broke out. In fact, rations were so poor that bad health kept a quarter of the hard labour convicts on the sick list. For De Beers, it was more economical to feed its convicts adequately. (67)

A final advantage that De Beers derived from convict labour lay in the prevention of diamond theft. Convicts were searched on entry to and exit from the station. They stripped in the search houses and went naked to their cells, where they assumed their blankets. When their term of imprisonment was over they were held for five days, naked and with large leather gloves locked on their hands. This was to ensure that they had not swallowed any diamonds in the hope of selling them once they were free. There is little doubt that such restrictions, together with rewards for found diamonds, did reduce the extent of theft. (68)

It has consequently been argued that closed compounds were introduced to prevent diamond theft. (69) Company managers and directors said this was the case in the 1880s and these historians have repeated this view. But, as has been suggested above, the model of convict labour presented other advantages to compound managers and company directors. Moreover, such a theft prevention view is too simple. As has been argued elsewhere (70), it abstracts one factor from a complex process of class struggle. It confuses a functional explanation with a causal one. It ignores the historical period in which closed compounds were introduced. It should be understood that closed compounds were introduced in the process of the development of underground mining, which required the investment of large amounts 
of capital. The rapid concentration and centralization of capital that underground mining required also dictated a more rigorous control of migrant labour, the unregulated scarcity and abundance of which had persistently hindered the process of capital accumulation. In fact, the closed compound system was the effective form in which the mine owners came to terms with migrant labour.

The great value of closed compounds for the mine owners lay in the constant supply of mine labourers they provided. Here recontracting was the key to the growth of a pool of experienced mine workers. Contracts commonly ran for two months in De Beers and Bultfontein mines while they lasted for three months in Kimberley mine. Africans recontracted for additional time in all the mines. In Kimberley mine "the majority re-engage for further periods up to nine months, in some cases remaining for eighteen months". (71) This, it seemed, was evidence of "just and reasonable" treatment of Africans. It should be remembered that recruitment was one of the ways of extending a migrant labourer's length of service on the mines. Since 1881, soon after its formation, the Kimberley Central had been recruiting Africans from Inhambane in Portuguese tast Africa. (72) When the company inaugurated closed compounds in April 1885, all its underground workers were recruited on unusually long one-year contracts. Similarly, before De Beers closed its open compound in 1886 "arrangements" were made with Chiefs in Basutoland, Bechuanaland and the Transvaal "for a continuous supply of labourers". (73) Recruitment generally led to longer contracts as a result of the distances of the recruiting areas from Kimberley or from delayed six monthly, rather than weekly, wage payment. Recruitment continued over the $1890 \mathrm{~s}$, becoming prominent during the labour shortage after the South African War and settling down to 10 per cent of the work force in the first decade of the twentieth century. (74) Thus, recruitment played a part in filling the compounds and in spinning out the length of a contract.

Lack of choice over recontracting also played a part in keeping up the compound complement. Between 1885 and 1891 no compound African was freely contracted. Compound managers sent a list of names to the Registrar of Natives, who renewed the labour contracts and sent them back to the compounds. "Those whose time has expired", reported one compound manager, "and who don't wish to recontract are discharged." (75) But matters were not that simple. Closed compounds enabled companies to regulate their labour supplies. When there were others to replace time-expired labourers all was well. But when competition from the Gold Fields became too strong or seasonal fluctuations too sharp, Africans were coerced into remaining in the compounds. And even after 1891 when the Registrar was allowed to perform his duties inside the compounds, there was little he could do to prevent management coercion.

Evidence of coercion lay in the large numbers of compounded Africans who remained uncontracted. In the largest compound, the De Beers West End compound, which increased its complement from 400 Africans in 1886 to 2,900 in 1895 (over half the De Beers work force), at least one-third to one half of the labourers were continually uncontracted. (76) A labour contract had always been a mixed blessing to Africans. Breaking a contract on the part of a labourer was a criminal offence. But it did offer some protection against employers. Legally contracts came to an end, at which point servants could withdraw their labour from one employer to offer it to another or some could leave for home. But without a contract, recourse to the Registrar was impossible. Africans were incarcerated in compounds in a legal noman's-land.

Moreover, lack of a contract could mean no work. For more Africans were compounded than were required for a full work force. The Kimberley Central, in the late 1880s, for example, generally employed only 1,000 out of the 1,200 Africans in their compounds. (77) At the same time De Beers men worked a four-day week. "To work 900 men", commented the compound manager, "we want 1,400 or 1,500 men for natives won't stand the whole week with the white miner." (78) Thus, with the development of underground mining it was crucial to have a constant supply of labour. Closed compounds not only provided the supply but also a reserve pool of labour to 
fall back on in times of strikes, disasters or periods of social tension between African miners and European supervisors.

There is ambiguous evidence as to whether compounds contained or exacerbated tension between white miners/contractors and black workers. With the introduction of underground mining, the labour process was fundamentally changed. Skilled white miners working with teams of twenty or more Africans were given contracts to excavate a set number of loads of blue ground a day. (79) As close supervision was impossible underground, piece-work wages, as opposed to time-work wages in the open mine, were introduced for the first time. Competition between contractors for bonuses put even greater pressure on African miners in experimental underground workings. Such competitive pressure on hand-drillers or loaders led to great conflict in the mines. In 1890 the situation underground was so bad that the Mine Inspector feared an African uprising in De Beers mine and the murder of white supervisors. Contractors did not bother to charge Africans with assault or disobedience as conviction on the evidence of African witnesses was improbable. This is not to suggest that violence was all directed at white miners. There were numerous white assaults on black workers. But, on balance, underground workings provided a refuge from mine authorities and created immense discipline problems for overseers and contractors. (80)

Above ground in closed compounds the situation was reversed. Compound management and compound guards held all the cudgels of coercion in their hands. They usurped the judicial functions of punishment reserved to the state in the Master and Servants Acts. They had their "own way of treating natives" and adopted their own "method of maintaining order". (81) Almost all compounds practised a system of fines. Fines were inflicted to protect companies "against the natural impulse of human nature, white and black, to do as little work as possible and get drunk whenever the occasion offers". (82)

When fines failed to discipline,more drastic measures were taken by compound management. In 1894 there was a dispute over work and wages in the Wesselton compound which "grew to such proportions that a riot ensued, during which the natives were fired on by the police and others, with the result that three of them were killed and seven wounded". (83) This was an example of extreme compound tension. But most disputes that ended in violence were over work conditions. Africans were well aware of the possibilities of underground disasters and refused to work in dangerous stopes or tunnels. Although workers could remain unemployed and unpaid in the compounds, the refusal to work when commanded was regarded as a punishable offence. And it was an offence dealt with by compound guards and not the Resident Magistrate. In one case, Charles Riordan, Head Guard of the De Beers West End compound, flogged a team of twenty-two Africans for refusing to work, confined them in a detention cell for five days and then dismissed them. The evidence of this thrashing - "the scars or wounds were still raw and about four inches in length" (84) - was still apparent a week later. Such treatment gave the De Beers compounds "a bad name amongst the natives". (85)

Despite the institutional coercion of the compound system, mine management argued that they improved the moral and social welfare of Africans. The temptations of liquor and sex in the townships was traded in for a larger wage packet at the end of a period of service. Even the Chiefs were pleased "because the boys take home sums of money". (86) But were Africans able to save more than in open compounds? Compound managers estimated that Africans saved from twenty-five to forty per cent more than before. One manager claimed that the average saving after six months service was £14. 10/-. (87) While it seems clear the possibility of saving increased, it is also clear that the possibility of eaming declined. Thus, while £l4 was indeed a handsome saving, such a saving, all other things being equal, could have been effected in half the time in the era of open compounds. Here, welfare was a side-effect of the primary purpose of closed compounds, which was to extend the length of a worker's spell of labour. 
Closed compounds were an early model of labour control for an industrializing South Africa. They bridged the gap between two modes of production. The laws of motion of a capitalist enclave in Kimberley began to extend its control over a labour supplying, pre-capitalist hinterland. The mine owners had struggled to control their supply of labour throughout the 1870s and 1880s. On the one hand, they wanted experienced labourers in their mines. On the other hand, they did not want an organized working class in their town. It was this contradiction that was bridged by the closed compound system. "Raw natives" became accustomed to mine work and not a threat to European property, liberty and security. This bridge was not one that was simply built by urban reorganization. It was crucially constructed by changing social and political relations in African chiefdoms in the countryside. The erosion of chiefly control over migrants had been a slow process. In 1888 Arthur David of the Bultfontein Mining Company noted that Africans had worked for his company for seven or eight years. (88) This group of semi-skilled Africans made up the nucleus of an African working class in Kimberley.

In the 1890s the compound system led to the proletarianization of unskilled mine labourers. By this time, at least, a significant number of Africans had been pushed permanently over the bridge into the mine economy. In 1902 Gardner Williams of De Beers wrote that some Africans had remained in his compounds continuously for ten years. (89) However, the normal pattern of life for the resident miner was an alternation between mine labour and periods of "resting" in the locations. Location landlords lived well off miners who rented rooms to recuperate their strength for two to six weeks before returning to the compounds. (90) Thus, the oscillation between location and compound kept up the complement of the De Beers work force.

\title{
Conclusion
}

Kimberley's compounds were more models of labour control than of social welfare before 1903. And the reason for this lay not so much in the penny-pinching economics of mining companies as in the historical position that diamond mining occupied in South Africa's industrial revolution. Diamond mining began that industrial revolution and had to prise a work force out of a pre-capitalist rural hinterland ruled by independent African chiefs. "It may well be", wrote Perrings,

\begin{abstract}
that where an industry did not have the means to exercise the necessary regulative controls over labour in the supplying areas, controls at the work place (in the compounds) were of heightened significance. (91)
\end{abstract}

Controls in the compounds were of even greater significance when production was monopolized by one leviathan company like De Beers Consolidated Mines. Not only did this facilitate a control over the labour supply but it also minimized African organization against exploitation in the mines. Kimberley had a more totalitarian system of labour control than imitators on mines further to the north. Kimberley's compounds differed from those on the Rand and in Southern Rhodesia in being closed, whereas they, in vaxying degrees, were not. But the greater compound selfsufficiency that this entailed in Kimberley did not lead to markedly higher standards of accommodation, diet and health-care until after 1903. Kimberley's compounds were as bad as those mine compounds on the Rand, in Southern Rhodesia and in Katanga in encouraging a death rate of enormous proportions. And that death rate has been hidden for far too long under the justification of compound philanthropy and the greater weight of mine owners' claims to protection against diamond theft. 
Notes

*I would like to thank Andrew Roberts, Shula Marks and Neil Andersson for comments on an earlier version of this paper.

(1) The South African Mines, Commerce and Industries, 25 April 1903, p 14.

(2) F Wilson and D Perrot (eds), Outlook on a Century: South Africa 1870-1970 (Johannesburg, 1972), p 301.

(3) British Parliamentary Papers (hereafter BPP), South African Mines (Mortality), 1904, Vol 13, Enclosure in No 6, p 9.

(4) BPP, Cd 2025, Correspondence Relating to Conditions of Native Labour Employed in the Transvaal Mines, No 4, 22 February 1904, p 41.

(5) See P Richardson, Chinese Mine Labour in the Transvaal (London, 1982), p 34.

(6) BPP, Cd 1897, Minutes of Proceedings and Evidence of the Transvaal Labour Commission (1904), "Report on Mortality Among Natives Employed on the Mines of the Witwatersrand", p 389; Cd 2025, Correspondence Relating to Conditions ... in the Transvaal Mines, No 17, Lyttelton telegram to Lord Milner, 9 May 1904, p 67.

(7) BPP, Cd 2025, Correspondence Relating to Conditions ... in the Transvaal Mines, Enclosure 1 in No 12, Memorandum from the Native Affairs Department, 31 March 1904, p 62.

(8) South African Parliamentary Papers, UG 34-1914, p. 161. I am grateful to Neil Andersson for bringing these statistics to my attention.

(9) C van Onselen, Chibaro: African mine labour in Southern Rhodesia, 1900-1933 (London, 1976), pp 131, 132.

(10) Tbid., p. 133.

(11) Ibid., p. 50 .

(12) Ibid., p. 51.

(13) Ibide, p. 57.

(14) C Perrings, Black Mineworkers in Central Africa (London, 1979), p 168.

(15) Ibid., pp 174-177.

(16) Tbid., p 202.

(17) S van der Horst, Native Labour in South Africa (London, 1946), p 83; G V Doxey, The Industrial Colour Bar in South Africa (London, 1961), pp 34, 35.

(18) See Rob Turrell, "Kimberley: labour and compounds, 1871-1888" in S Marks and R Rathbone (eds), Industrialisation and Social Change in South Africa: African class formation, culture and consciousness 1870-1930 (Iondon, 1982), pp 45-76.

(19) Cape Archives Depot (hereafter CAD), NA 455, Leary to Under Secretary for Native Affairs, 9 March 1889; Cape Parliamentary Papers (hereafter CPP), Blue Book for Native Affairs, G4-190, p 57.

(20) CPP, Reports of Inspectors of Diamond Mines (hereafter RIIM), G22-189, p 9.

(21) A E Sawyer, Mining at Kimberley (Newcastle-under-Lyme, 1889), p 39.

(22) J J Van Helten, "British and European economic investment in the Transvaal with specific reference to the Witwatersrand Gold Fields and district, 18861910" (PhD thesis, University of London, 1981), Appendix IV, Table 18; van Onselen, op. cit., p 50; R V Turrell, "Capital, Class and Monopoly: the Kimberley Diamond Fields, 1871-1889" ( $\mathrm{PhD}$ thesis, University of London, 1982), Appendix II, Table 35.

(23) CAD, IND 1/220, Captain Erskine to Secretary for Lands and Mines, 9 April 1886. 
(24) Diamond Mining Company.

(25) "The GM De Beers has always been recalcitrant on safety regulations and will probably be more so as the Company acquires private power." (CAD, IND $1 / 327$, Department Memo, 8 July 1889, f 3330.)

(26) University of Cape Town, Judge Papers B 47, Commission of Enquiry into the De Beers Disaster, 4 August 1888.

(27) G Williams, The Diamond Mines of South Africa (New York, 1902), Vol II, p 39.

(28) The small-pox epidemic lasted from October 1883 to Jamuary 1885 and the official number of deaths was 700 out of 2,311 cases. In sharp contrast, 4,000 people died in Cape Town from small-pox in the space of a few months. See R V Turrell, "Capital, Class and Monopoly", pp 258-261.

(29) "Report on the Sanitary Condition of Kimberley", Diamond News, 29 March 1879. The total population of Kimberley (excluding the smaller township of Dutoitspan) was taken from the 1877 census as 14,169 (6,574 Furopeans and 7,595 0thers). The European death rate was 40 per thousand.

(30) The 1888 figure is calculated from a Kimberley (excluding Beaconsfield) population of 28,000 (12,000 Europeans and 16,000 Others). See R V Turrell, "Capital, Class and Monopoly", Appendix II, Tables 9 and 34.

(31) CPP, Commission on Liquor Laws, G1-190, evidence of G Hudson, Q 6532.

(32) CPP, Commission on Convicts and Gaols, G2-'88, First Report, p ii.

(33) Tbid., evidence of Bradshaw, Q 1449-1454; evidence of Dr Grimmer, Q 688-699. See also Appendixes $\mathrm{G}$ and $\mathrm{K}$.

(34) CAD, CO 3556, No 13, Report of the District Surgeon, Charles Budler, for 1886.

(35) "Report on the Sanitary Condition of Kimberley", Diamond News, 29 March 1879.

(36) CPP, Reports of the District Surgeon, G3-186, 22, G19-187, 18; CPP, Commission on Liquor Laws, G1-190, Appendix I, 1058.

(37) CPP, Blue Book on Native Affairs, G52-1901, p 74.

(38) "Board of Health", Daily Independent, 10 November 1883, 17 November 1883; "Kimberley Mining Board", Diamond Fields Advertiser, 9 August 1884;

"Kimberley Town Council", Daily Independent, 12 Februaxy 1887.

(39) CAD, NA 455, Leary to Under Secretary of Native Affairs, 9 March 1889; CPP, Blue Book on Native Affairs, G4-190, p 57.

(40) CAD, NA 4Il, Craven to Secretary of Native Affairs, 23 June 1896.

(41) CAD, IND 1/369, Craven to Commissioner of Crown Lands, 16 October 1891, L550.

(42) CPP, Blue Book on Native Affairs, G52-1901, p 74.

(43) University of Cape Town, Judge Papers B 47, Commission of Enquiry into the De Beers Disaster, 4 August 1888.

(44) CAD, NA 411, Barnes to Under Secretary for Native Affairs, 13 July 1896.

(45) CPP, Commission on Convicts and Gaols, G2-'88, First Report, p ii.

(46) CAD, NA 411, Barnes to Under Secretary for Native Affairs, 13 July 1896.

(47) CPP, Commission ... into the Diamond Trade Acts, G3-'88, evidence of $\mathrm{J}$ Gifford, Q 2186, 2199, 2218, 2219, evidence of F R Thompson, Q 113; CPP, Labour Commission, G3-'94, evidence of S Dallas, Q 17440 .

(48) CPP, Commission on Liquor Laws, evidence of Dr J E McKenzie, Q 6871, 6886, 6887 . 
(49) Year

Average number

total deaths

total yearly death of workers* rate per 1,000

\begin{tabular}{lrrr}
\hline 1897 & 6,942 & 333 & 47.97 \\
1898 & 7,934 & 343 & 43.23 \\
1899 & 8,022 & 368 & 45.87 \\
1900 & 5,468 & 365 & 66.75 \\
1901 & 6,292 & 684 & 108.70 \\
1902 & 6,603 & 497 & 75.27 \\
1903 & 7,273 & 317 & 43.59 \\
1904 & 7,858 & 129 & 16.42 \\
1905 & 11,243 & 387 & 34.42 \\
\hline
\end{tabular}

*Excludes Wesselton mine.

(Statistical Registers of the Colony of the Cape of Good Hope, 1897-1905.)

In addition to compound dwellers there were another 8,000 Africans who lived in the locations. The death rate of the total African population was well below that of the African mine work force. (CPP, Blue Book on Native Affairs, G7-'192, pp 17, 18.)

(50) CPP Commission on Convicts and Gaols, G2-'88, evidence of F R Thompson, $Q 186$.

(51) CAD, C0 3454, No 244, F S P Stow telegram to Graham, 4 October 1884, Wright telegram to Graham, 11 October 1884, Under Colonial Secretary to Judge, 12 January 1886; CO 3556, No 51, Judge to Under Colonial Secretary, 4 October 1887; CPP, Commission on Convicts and Gaols, G2-'88, First Report, p iv.

(52) CPP, Commission on Convicts and Gaols, G2-'88, Second Report, p xlii.

(53) R F Sieborger, "The Recruitment and Organization of African Labour for the Kimberley Diamond Mines" (MA thesis, Rhodes University, Grahamstown, 1976), pp 129-131.

(54) CPP, RIDM, G40-'86, p 12.

(55) Ibid.

(56) CPP, RIIM, G22-'89, p. 9.

(57) CAD, CO 3556, No 28, Judge to Under Colonial Secretary, 19 July 1887; C0 6410, No 23, Scott to High Sheriff, Cape Town, 18 April 1889.

(58) Some 8,708 persons were convicted each year between July 1884 and June 1887 and sent to the Kimberley gaol. Of these 3,096 were convicted each year for pass offences. Double this number were arrested for this offence each year. (CPP, Commission on Convicts and Gaols, G2-188, First Report, p ii.)

(59) In 1887 there was an average of 2,238 convicts in the Cape Colony, of whom 870 were imprisoned in Kimberley. (Cape Hansard, 1888, pp 58, 59.)

(60) CPP, Labour Commission, G3-194, evidence of R G Scott, Q 17446.

(61) CAD, CO 6427, No 51, Scott to Law Department, 22 April 1890.

(62) Ibid.

(63) Cape Hansard, 1892, p 10.

(64) "De Beers IMC, Annual General Meeting", Daily Independent, 8 May 1886; CPP, Commission on Convicts and Gaols, G2-188, Second Report, xliii; CAD, CO 6427 , No 46a, Enclosure in R G Scott to Law Department, 18 March 1890; CPP, Select Committee on Trade and Business in Griqualand West, A7-191, evidence of G F Williams, Q 4245; CPP, Labour Commission, G3-194, evidence of R G Scott, Q 17318, 17322.

(65) Statistical Registers of the Colony of the Cape of Good Hope, 1890-1905.

(66) CAD, CO 3526, No 166, Judge to Under Colonial Secretary, 14 April 1886; CPP, Commission on Convicts and Gaols, evidence of S Dallas, Q 1037; CAD, CO 6396, No 58, Scott to Visiting Magistrate, 14 May 1888.

(67) "Convict Strike", Daily Independent, 9 August 1884; CAD, CO 3454, No 227, , Under Colonial Secretary telegram to Judge, 18 November 1884; CO 3556, No 70 , Bradshaw to Judge, 6 December 1887. 
(68) CAD, CO 6396, No 115, Macleod Robinson to Under Colonial Secretary, 13 August 1888 .

(69) van der Horst, op. cit., pp 79, 82; Doxey, op. cit., p 34; J Smalberger, "IDB and the Mining Compound System in the 1880s", South African Joumal of Economics, 42 (1974), pp 398-414; van Onselen, op. cit., p 130.

(70) Turrell, "Kimberley: labour and compounds, 1871-1888", loc.cit, pp 45-76.

(71) CPP, RIDM, G22-'89, p 6.

(72) "Report for Seventh Quarter", Diamond News, 4 March 1880; University of Cape Town, Smalberger Papers, Kimberley Central DMC, Directors' Minute Book I, $5 \mathrm{July} 1881$, f 112, 20 February 1882, f 236.

(73) N Rouillard (ed), Matabele Thompson: his Autobiography and Story of Rhodesia (Johannesburg, 1957), p 42.

(74) van Onselen, op. cit., n 131.

(75) CPP, Commission ... into the Diamond Trade Acts, G3-'88, evidence of $J$ Gifford (Kimberley Central DMC), Q 2200.

(76) CAD NA (B 1475), Stephens to Civil Commissioner, 17 May 1895.

(77) CPP, Commission ... into the Diamond Trade Acts, G3-'88, evidence of $J$ Gifford, Q 2222.

(78) Tbid., evidence of F R Thompson, Q 180; CPP, Commission on Convicts and Gaols, G2-188, evidence of $F R$ Thompson, $Q 186$.

(79) South Africa's first legislated industrial colour bar was introduced with the development of systematic underground mining in Kimberley. In December 1885 discrimination with respect to blasting was formally promulgated under the Rules and Regulations of the 1883 Mining Act. In every case blasting was to be "carried on under the supervision of a European experienced in blasting" and "no persons under eighteen years of age and no native is to be permitted to manipulate explosives or prepare the same for blasting or other purposes". (South African Library, Kimberley Central IMC, General Regulations, "Special Rules for Regulating Blasting Operations in the Kimberley Mine", 27 February 1886, p 26.) Four years later the regulations stated bluntly:

No native shall work or be allowed to work in any mine, whether in open or underground working, excepting under the responsible charge of some particular white man as his master or 'baas'.

( $C A D$, IND 1/285, General Rules and Regulations for the Working of Diamond Mines, 1 July 1889, $f$ 1563.)

(80) CAD, IND 1/346, Captain Erskine to Chairman of De Beers Consolidated, 29 May 1890.

(81) CAD, NA 455, J G Leary to Under Secretary of Native Affairs, 7 October 1889.

(82) CAD, NA 455, J Davis Allen (Manager of the Anglo-African IMC) to J G Leary, 2 September 1889.

(83) CPP, Blue Book on Native Affairs, G8-195, p 20.

(84) CAD, NA 411, Barnes to Secretary of Native Affairs, 13 July 1896.

(85) CAD, NA 455, J G Leary to General Manager, De Beers Consolidated, 12 February 1891.

(86) CPP, Commission ... into the Diamond Trade Acts, G3-188, evidence of F R Thompson, Q 104.

(87) CPP, Commission on Liquor Laws, G1-190, pp 1039-1043.

(88) CPP, Commission ... into the Diamond Trade Acts, G3-188, evidence of A Davis, Q 2846.

(89) G F Williams, The Diamond Mines of South Africa, Vol II, p 57.

(90) CPP, Labour Commission, G3-'94, evidence of W H Powell, Q 17188, 17182, 17183.

(91) Black Mineworkers in Central Africa, p 163. 